\title{
An Evaluation of Nigeria's Management of Anti-Corruption Strategies
}

\author{
Blessing Ose Oligbi (Ph.D) (Corresponing Author) \\ Department of Economics and Development Studies \\ Igbinedion University, Okada \\ Tunde Agara (Ph.D) \\ Department of Political Science and Public Administration \\ Igbinedion University, Okada
}

\begin{abstract}
Corruption is a reality that afflicts all of humanity, a phenomenon that is not the specialty of any people or nation, it takes many forms nevertheless, and it is a universal cancer. This paper primary aim is to assess all of the adopted strategies and why they have failed given the fact that rather than abate, corruption has become more entrenched and endemic. Nigerians have suffered irreparable damage from deliberate, deliberative and pre-meditated collective looting of the public treasury by criminally-minded politicians and their bureaucratic surrogates. Waste, mismanagement, squander-mania, and profligacy have become the name of the game at the expense of the delivery of basic public goods, and services. Our submission is that former attempts to cleanup corruption have all failed because the leaders do not understand the dialectics of corruption and the strategies were not properly directed to address it. This is, of course in relation to other faults that have been identified earlier. Every attempt at handling corruption had adopted a holistic conceptualization of corruption which has led to the belief in a uni-linear notion of causation of corruption and a rather simplistic perception of its solution. Our thesis is that corruption in Nigeria can be categorized into three types; political corruption, bureaucratic corruption and corruption of the bureaucratic process. It is within this conceptualization of corruption that its incidents, endemic nature, and prevalence can be understood and efforts to eradicate it can yield results. It is within this conceptualization that we can understand that corruption is in a systemic relation to each other, one begets the other and so any attempt to tackle one while leaving the other will end in futility.
\end{abstract}

Key words: Anti- corruption, Corruption, Evaluation, Management, Nigeria

\subsection{Introduction}

The rather all-pervasiveness of corruption has made Caiden (1979:294) to declare that it is something that can no longer be "regarded as exotic subjects related to under-development, a stage which it was assumed, Western societies have long outgrown." This projects corruption as a reality that afflicts all of humanity, a phenomenon that is not the specialty of any people or nation, and although it "takes many forms nevertheless, it is a universal cancer" (Eigen, 2000). But to be sure, corruption seems to be more endemic in some nations more than others; especially in those nations where there is a fair share of public-private sector partnerships in all facets of the economy; international linkages between governments and western and increasingly eastern trans-national corporations (TNCs); as well as in state institutions dedicated to the deregulation mantra. The TI Corruption Perceptions Index 2010 results show that only about a quarter of the 178 countries sampled scored over five in a scale from ten (highly clean) to zero (highly corrupt), suggesting, according to the report, "a serious corruption problem" across the globe.

It would seem that Nigeria has had more than its own share of corruption and corrupt leaders who had "deepened and entrenched patterns of corruption" from the Ibrahim Babangida (1985-1993) and the Sani Abacha (1993-1998) years (Human Rights Watch, 2007b:13) to the present civilian government which took off on 29 May 1999. As Williams (2007:13) had noted, rather than bringing succour, democracy had only engendered "an anti-democratic political elite" which has turned state and federal spaces of governance to sites of "feeding frenzy, of permanent plundering by a succeeding band of marauders." This amounts to elite conspiracy against "democratic growth and the genuine economic and political transformation of Nigeria." Williams had, however, omitted the local government councils in his analysis where the extent and intensity of corruption had been described by Nuhu Ribadu, the chairman/chief executive of the Economic and Financial Crimes Commission (EFCC), as "not even corruption but gangsterism. It is organized crime" (Human Rights Watch, 2007: 19). 
The private sector is not exonerated from this corrupt jamboree. In an earlier study conducted using the five year reports of the Public Complaints Commission (PCC) in Nigeria, we discovered that private organizations have the largest number of complaints bordering on corruption and corrupt practices (Agara 1990). As a former Detroit's Mayor; Hazen Pingree, has been quoted to say, "...the corporations are responsible for nearly all the thieving with which cities are made to suffer from their servants. They seek almost uniformly to secure what they want by means of bribes and in this way they corrupt our councils and commissions" (Griffith 1974:45).

Today, Nigerians have suffered irreparable damage from deliberate, deliberative and pre-meditated collective looting of the public treasury by criminally-minded politicians and their bureaucratic surrogates. Waste, mismanagement, squander-mania, and profligacy have become the name of the game at the expense of the delivery of basic public goods, and services. For instance, virtually all the headlines of January 19, 2016 carried the news of only 55 Nigerians stealing N1.34 trillion, one-third of which the Vanguard Newspaper analyzed as being sufficient to provide 635.18 kilometers of roads, 39 ultra-modern hospitals per state, 183 schools, educate 3,974 children from primary level to tertiary level at 25.24 million per child and build 20,062 units of 2-bedroom houses. Contrary to this, experience in Nigeria has actually shown that successive governments even including those that are steeped in corruption have played lip-service to its eradication; others have assumed a sanctimonious attitude towards it, while some have adopted a crusading posture for its eradication (Agara, 2008). This paper primary aim is to assess all of the adopted strategies and why they have failed given the fact that rather than abate, corruption has become more entrenched and endemic.

\subsection{What really is Corruption? Perspectives, Theories and Definitions}

Three mutually exclusive hypotheses in contemporary corruption studies appear rather fascinating but useful in understanding and explaining the different perceptions of corruption. The first, 'grease the wheels,' postulates that corruption may speed up a sluggish bureaucracy and raise efficiency. A neo-functionalist theory, it argues that in countries with faulty institutions and absent public-enriching aspects of governance, corruption may help citizens to better take advantage of factor endowments. The second, 'sand the wheels' hypothesis, contends that in a context where corrupt public servants and elected officials can cause delays so they could get opportunities to extract bribes, individual bribers can improve their personal situations at the expense of the polity. The hypothesis is premised on the fact that an increase in corruption will reduce efficiency even in a deficient institutional context. The third is that corruption is not all that 'bad'; it does perform some useful social and economic function (Leff, 1964; Nye, 1967).

However, citing the examples of the political life in $19^{\text {th }}$ century America and $18^{\text {th }}$ century Britain, Huntington (1972:59) has muted that corruption in these two countries coincided with the advent of industrialization, "the development of new sources of wealth and power and the appearance of new classes making demands on government." In arguing for this thesis, Huntington submitted that there are three connections that logically linked corruption with modernization. The first is that;

"Modernization involves a change in the basic values of the society,

in particular it means the gradual acceptance by groups within the

society of universalistic and achievement based norms, the emergence

of loyalties and identifications of individuals and groups with the

nation-state, and the spread of the assumption that citizens have

equal rights against the state and equal obligations to the state".

The second connection can be seen from the fact that "modernization contributes to corruption by creating new sources of wealth and power, the relation of which to politics is undefined by the dominant traditional norms of the society and on which the modern norms are not yet accepted by the dominant group within the society". Corruption provides a means for elite circulation, the assimilation of new groups or members into the political system, because the political system has been unable to provide other legitimate and acceptable means. McMullan (1963:196) has pointed out that in Africa and Nigeria is not an exception, corruption threw "a bridge between those who hold political power and those who control wealth, enabling the two classes, markedly apart during the initial stages of African nationalist governments, to assimilate each other". Corruption, therefore, provide the comprador middle class the only way to become participants in the political system. Their wealth enables them to buy the necessary votes which would ensure their future entrenchment and hegemony over the political apparatus. Thus, a corrupt act has been performed; money is exchanged for access to political power.

Lastly, "modernization encourages corruption by the changes it produces on the output side of the political system". In explaining how a political system works, Almond and Powell (1966) have shown that this depends on its capabilities; namely, the regulative capacity (that is, rule making), distributive capacity (that is, ability to distribute goods and services), responsive capacity (that is, ability to respond to demands) and extractive capacity. 
These capacities increase and expand as a governmental system becomes modernized, that is, the political system legislates and makes rules whose application becomes broader still to encapsulate the total system and all strata. The more laws and regulations made by the political system to ensure order and harmony, the more some groups in the society are put at what they perceive as a disadvantage and consequently, a potential source of corruption is generated as the affected groups scheme for ways to by-pass the stringent and inhibiting rules. As Huntington (1972:62) has noted;

"The multiplication of laws thus multiplies the possibilities of corruption.

The extent to which this possibility is realized in practice depends in large

part upon the extent to which the laws have the general support of the

population, the ease with which the law can be broken without detection,

and the profit to be made by breaking it. Laws affecting trade, customs,

taxes plus those regulating popular and profitable activities such as

gambling, prostitution, and liquor, consequently become major incentives

to corruption. Hence in a society where corruption is widespread the passage

of strict laws against corruption serves only to multiply the opportunities

for corruption".

These different perspectives and approaches have further made the understanding of corruption more difficult. The conceptual and academic difficulty is further compounded by the fact that the study of corruption in any society is an unusually difficult task (Smelser, 1971:12) and it is made so by the fact that the processes and acts of corruption itself are shrouded in secrecy (Brasz, 1963:117). The empirical study of corruption requires that the actual practices and acts of corruption be identified and so labelled. But what passes for corrupt practices in one society may not be so called in another. This has aggravated the problem of conceptualization and definition of corruption; nevertheless, it is a concept that must be understood before any meaningful discussion can be productive. In spite of all these, scholars are all agreed that corruption alludes to a psychological state of putrefaction of both the society and its people.

Most definitions of the concept stress on the idea of corruption as behaviour resulting in private gain albeit at public expense. Mcmullan (1970:5) has put it this way;

"A public official is corrupt if he accepts money or money's worth

for doing something that he is under duty to do anyway, that he is

under duty not to do, or to exercise a legitimate discretion for

improper reasons".

Other definitions have indicated that corruption is a subversion of the objectives of the bureaucracy, public morality and health. Ekhomu's (1980:3) definition puts it thus;

"...corruption ....is the deliberate or inadvertent thwarting of the implementation process through either the acceptance or asking

for bribe, sub-optimal utilization of available resources due to

selfish motivations, and performance or non-performance of one's

official duties with the view of achieving a private gain and which

does not directly aggregate in the community good".

Generally, people see corruption as a practical problem involving the "outright theft, embezzlement of funds or other appropriation of state property, nepotism and the granting of favours to personal acquaintances, and the abuse of public authority and position to exact payments and privileges" (Harsch 1993:33). Nye (1967:419) argues that corruption involves "behavior which deviates from the normal duties of a public role because of private-regarding (family, close clique), pecuniary or status gain; or violates rules against the exercise of certain types of private-regarding influence. Some definitions have emphasized that corruption is an abuse of official power. Benson (1978:xiii) has defined it as "all illegal or unethical use of government authority as a result of consideration of personal or political gain." Bayley (1966:720) has also argued that not all corrupt acts involved the exchange of money. According to him, corruption is "a general term covering misuse of authority as a result of consideration of personal gains which need not be monetary." Rose-Ackerman's (1978:1-2) conceptualization of corruption as the use of illegal market mechanisms in allocative decisions set aside for the democratic political system and Gardiner and Lyman's (1978:5) definition that it is "the exchange of money or other material goods for preferential treatment by public officials" described corruption in terms of a theory of market.

Other conceptualizations have tended towards aiding understanding of the phenomenon by being conventional or situational specific. These definitions tend to describe corruption in terms of specific laws, rules and values which have been violated. 
Legal definitions, in this regard, are precise, descriptive but problematic in that they are inadequate as a basis for comparison across jurisdictions. Of all these definitions, the useful ones have always been the simple ones that merely equate corruption with bribery and extortion which need not be in monetary terms only (Agara, 1995:65). Although the literature and definitions are inexhaustible, one thing becomes clear and this is that in every acts of corruption, the society and public loses and the individual perpetrator gains albeit at the expense of both the state and others. Corruption thus enhances only private gains at public loss, or as Werlin (1973:73) has put it simply; it is the "diversion of public resources to non-public purposes."

\subsection{Historicising Corruption in Nigeria}

To historicise, political corruption was the precursor and the historical antecedent to bureaucratic corruption in Nigeria. It is the specific performance of a political act in exchange for an economic sanction or favour in such situation where money is seen to 'soil' the relationship and the exchange itself becomes sanctified by cultural or mutual expectations. Within our culture where exchange of gifts is culturally accepted, and where these gifts are sometimes given without soliciting amongst individuals and not necessarily during any special occasion, there is generated an acceptancesyndrome which cloaks such exchange in many disguises. Even the Fifth Schedule of the Constitution which addresses the behaviour of public servants is in agreement with this exchange of gifts as a cultural and traditional act which may not hold any ulterior motive but which in most cases actually does. Not all gifts come without strings attached. It is the strings attached that make such gifts suspect. Thus we define political corruption within the peculiarity of our cultural norms as those acts perpetrated by elected representatives of the people who man the political machinery of the state, acts which are not performed in the general interest of the voters and populace, but solely for their own personal gains and to curry certain immediate or futuristic favours (Agara 1995:66). Nwabuzor (2003:243) has widened the scope of political corruption to include the "fraudulent and/or forceful acquisition of power over a group of people." Thus, as Goodman (1990) had also stated, political corruption usually includes activities such as vote-rigging, registration of unqualified, dead, or non-existent voters, purchase and sale of votes, and the falsification of election results.

The infestation of the bureaucracy took the form of bureaucratic corruption and had two interrelated historical antecedents. The bureaucrats were aware of the nefarious activities of their political heads; the ministers and the politicians. They saw how overnight they became rich through political patronages, gifts, grafts and bribes (Corpuz, 1960:6-8). Since the tendency towards acquisitiveness is an inherent trait of all humans and the politicians seemed to have made it their exclusiveness, all that the bureaucrats had to do was bid their time. That time soon came and they were quick to hop on the bandwagon of corruption, albeit with disastrous consequences for the civil service. Closely related to this was the opportunity that was offered them and which led to the erosion of the traditional ideals and standard of bureaucratic behaviour. The long awaited opportunity presented itself during the Gowon's period which saw the inclusion of the bureaucrats in the policy making organ at both states' and national levels. This was as a result of the military immaturity at civil governance. Since the politicians had been discredited, the only organ that was available to give advice and guidance to the military administrative machinery was the bureaucracy. As Adamolekun (1985) puts it, the higher civil servants found themselves no longer in the corridor of power but in the bedchamber of power. The reliance of the military administrators on the higher civil servants for guidance and advice inadvertently led to the latter's inclusion in the highest policy making organ at both the state and national levels.

The third type in this systemic trilogy is what we have labelled as the corruption of the bureaucratic process. This approximates corruption in the routine course of government business. On one hand, it is individualistic in the sense that an employee performs secret money-making enterprise by stalling or delaying the normal process and speed of work. In bureaucratic language, this is called bureaucratic red-tapism. On the other hand, it is collective and socialized in the sense that this type of corruption follows the prevailing norm, it appears regularized and institutionalized because almost everybody is involved and the clients can describe the illegal process and rates for every services to be rendered. Most often, the proceeds are shared among the members of the syndicate which consist of low and middle level officers. This is the logical fall-out of bureaucratic corruption, the lower level officers saw their bosses, the higher civil servants profiting from illegal acts and they embarked on their own profiteering rackets. Corruption of the bureaucratic process is the lowest in the triad but it is also the most virulent and pervasive. It presents a picture of people with bastardised sensibilities, a society that has become so stymied in corruption that it has now become institutionalized and has shaped and conditioned cultural attitudes and behavioural patterns to conform with and accept it. In such situation, the society becomes traumatised by (1) widespread occurrence of dishonesty among employees, (2) individual corruption is protected by colleagues and all, (3) honest employees become deviants, are stigmatized, isolated and may receive harsh treatments from both bosses and colleagues alike, (4) individuals engaged in systematic corruption become so accustomed to it that when caught, they readily claim innocence, unfair treatment and victimization, and 
(5) collective involvement and guilt among members in such administrative units encourages the rationalization of existing internal procedures and no serious efforts are made at controlling or curbing unethical activities. This type of corruption pervades the whole social structure and hierarchy of the society and its public organizations. As the Caidens (1977:276) have aptly noted, corruption of the bureaucratic process presents;

"A situation where wrongdoing has become the norm, and the standard accepted behaviour necessary to accomplish organizational goals according to notions of public responsibility and trust has become the exception, not the rule. In this situation, corruption has become so regularized and institutionalised that organization supports back wrongdoing and actually penalized those who live up to the old norms".

\subsection{An Evaluation of Some Nigerian Strategies and Why They Failed}

In his maiden speech as the civilian head of state in the 4th Republic, President Obasanjo assured the nation that his government would tackle the corruption monster "head on at all levels." His premise was that "no society can achieve anything near its full potential if it allows corruption to become the full-blown cancer it has become in Nigeria" (cited in Adebanwi, 2012). In another speech, titled From Pond of Corruption to Island of Integrity, on November 7, 2003 to mark the tenth anniversary of the founding of TI, Obasanjo claimed that his government had taken measures and established institutions that had started "to deepen the governance reform measures that should in the next four years translate into various oasis of integrity in Nigeria". The measures and institutions mentioned by the former president included open and competitive tendering of government contracts; anti-corruption campaigns (supposedly) involving 'all public officials and the president'; and public sector reforms to reduce the opportunity for corruption. Others are the establishment of a Due Process mechanism (or the Public Procurement Commission) that vets and trims government contracts and a Policy and Programmes Monitoring Unit in the president's office; the putting in place of the EFCC and signing on to the Extractive Industry Transparency Initiative (EITI) meant to shore up information and transparency in the towering, but decrepit oil and gas industry. President Jonathan in his inauguration speech on 29 May, in general terms promised that "the bane of corruption shall be met by the collective determination to rid our country of this scourge. The fight against corruption is a war in which we must all enlist, so that the limited resources of this nation will be used for the growth of our common wealth". In a September speech at the opening of the $8^{\text {th }}$ national seminar on economic crimes at the EFCC offices, the president spoke again on corruption: "we will give all the necessary support and encouragement to all the anti-corruption agencies to vigorously enforce the enabling anticorruption laws". He would add, perhaps for effect, that his government "will not protect any so-called sacred cow"; it will also ensure that "the wheel of justice ... runs its full course in tackling anti-corruption cases". Given the fact that there is no dearth of attempts to reform the society and cleanup corruption, why is corruption still pervasive?

To date, Nigeria has adopted the legal-rational, political and administrative methods to combat corruption. The political strategy has not gone beyond mere rhetoric by leaders who played the corruption campaign as a political agenda. Many times, successive governments have been probed by succeeding governments, reports and findings submitted and eventually politicised with nothing concrete coming out of it. Rather, the process of inquiring itself becomes politicised and opportunity to make money, membership of the investigating committee becomes embroiled in controversy that it makes mockery of the whole thing. Many government's probe commissions white paper report have been buried that news of such probes do not excite the populace anymore. However, only two governments have adopted the administrative strategy of purging the public service and two have attempted to actually reform the service. The public service had undergone many attempts at tinkering with it. Prominent among these attempts are; The Hunt Committee (1934), The Bridges Committee (1942), The Tudor-Davies Commission (1945), The Harragin Commission (1946), The Smaller Commission (1946), The Foot Commission (1948), The Phillipson-Adebo Commission (1953), The Lidbury Commission (1954), The Gorsuch Commission (1955), The Mbanefo Commission (1959), The News Commission (1959), The Morgan Commission (1963), The Elwood Commission (1966), The Adebo Commission (1971), The Udoji Commission (1972), The Phillips Commission (1988) and The Ayida Panel (1994).

However, if we distinguish between administrative reform and administrative change (Agara, 1992), only two out of all these qualified as reform and these are Udoji and Dotun Philips, initiated under the military governments of Generals Gowon and Babaginda respectively. Although the reforms were not specifically directed at eliminating corruption as much as they were directed to make the service more effective and productive in the discharge of its duties, the reforms, nevertheless, have impact on the service by showing the civil servants that the eyes of the governments were upon them. 
The involvement of the higher civil servants in governance and policy making under General Gowon tainted the civil service and therefore, necessitated that the in-coming Murtala Muhammed regime demonstrate a strong will and sincere intention to combat corruption between 1975 and 1979 which led to the first ever purge of the civil service.

However, the government was unable to rid the society of this disease by the time of his assassination. It is very ironic that the regime which had positioned itself to fight corruption did not understand the dialectics of the social ill it sought to combat. The second of such purges was by the government of General Buhari whose government stated its commitment right from the onset to eradicate corruption, uphold the principle of public accountability and the development of an improved work ethics amongst the Nigerian workers. As Adamolekun (1985:89) pointed out, this double commitment to fight corruption and uphold the principle of public accountability, adds up to a creative-cumpreventive strategy. By 1984, the most practical demonstration of this regime's determination started with the probes of federal, states and local governments' functionaries and this involved every public sector organizations. Unlike other probes before it, notably those of 1966-1969, and 1975-1976, the decree empowering the probe; Recovery of Public Property (Special Military Tribunal) Decree no. 2 of 1984 included within it a legal backing for the exercise and even stipulated jail terms for those found guilty. For the first time, punishment as a deterrent became the conscious policy of the government and not as acts of victimization. In spite of arguments as to the draconian and harsh sentences meted out to those found guilty, the fact still remains that sanity prevailed if only for the duration of the government before it was overthrown by government of General Babaginda.

Of all these, the most conscientious attempts to combat corruption have been the legal strategy with the setup of the Public Complaints Commission (PCC) and the established of the Economic and Financial Crimes Commission (EFCC). The PCC is still in existence but studies have shown that it has been rendered useless and ineffective by the very Act establishing it. Extant regulations and rules guiding its modus operandi have emasculated it from being a truly ombudsman system. For instance, it was prohibited to investigate any allegations or complains against any of the arms of the military and it does not possess the powers to prosecute (Agara, 1989, 1990b). Although its performance cannot be said to be of a sterling quality, it has, given the harsh environment created for it by its inability to prosecute, performed admirably well. The EFCC is a recent creation than the PCC. Like the PCC, the EFCC has been operating within an extremely harsh and hostile ecology. In regards to it, it would seem that neither the central government nor the National Assembly appears to sing from the same anti-corruption hymn sheet as the anti-graft commission. It has very few sympathizers and allies in the corridors of power. Twice the Assets Forfeiture Bill it sponsored failed to get legislative assent. In September, Waziri cried out that some people in high places posing as friends and associates of prominent persons in society have been interfering with the commission's investigations and obstructing its efforts to bring suspected financial criminals to justice. Little wonder then that in its eight years of existence, the EFCC has recorded no more than modest success, despite its tendency towards the sensational and a bullish approach. Its investigators have been accused of being ruthlessly efficient, not hesitating to break the law in order to enforce the law (Human Rights Watch, 2011:9-10). It has made little headway with the powers-that-be. In May 2011, EFCC announced the names of nine out-going governors against whom it would bring charges once their immunity was removed. By the time it eventually swung into action in October, the list had shrunk to only a trifle four. The prosecution for alleged corrupt enrichment of fourteen former state governors in power between 1999 and 2007 has made very little progress, save for isolated pockets. Some of them have since been elected to other political positions. For the record, the governors in question are mainly from the ruling PDP and they include: Joshua Dariye (Plateau), Abdullahi Adamu (Nasarawa), Abubakar Audu (Kogi), Saminu Turaki (Jigawa), Orji Uzor Kalu (Abia), Boni Haruna (Adamawa), and Mike Botmang (Plateau). Others are: Ayo Fayose (Ekiti), James Ibori (Delta), Lucky Igbinedion (Edo), Chimaroke Nnamani (Enugu), Jolly Nyame (Taraba), Rasheed Ladoja (Oyo), and Attahiru Bafarawa (Sokoto) (Adeseri, 2011).

Since 2003, the EFCC has recovered about $\$ 11$ billion in stolen public funds, and achieved over 600 prosecutions. But only 30 NPPF have been arraigned on corruption charges, with prosecution rate dismally poor. By August 2011, no politician was serving jail time for alleged crimes (Human Rights Watch, 2011:1). It would seem therefore that EFCC success lies elsewhere, fighting apolitical financial crimes such as Internet and Advance Fee Fraud (419) crimes, a large chunk of its original mandate. It recorded, in four years, no less than 250 convictions of mostly non-public office holders, including a few federal lawmakers. Under Ribadu's watch, the commission also recovered about $\$ 5$ billion in cash and property. By the time of Ribadu's controversial removal in 2008, over 2000 cases of this nature were pending (Adebanwi \& Obadare, 2011:195, 202). By contrast, only four convictions of strategically placed politicians were realized between 2003 and July 2011. Out of this number, only one - Olabode George - at a trial, the remaining three through plea bargains (Human Rights Watch, 2011:19-20). As has been argued, however, only when "nationally prominent political figures' and 'politically exposed persons' are successfully prosecuted and jailed could the EFCC and other anti-graft agencies deem their work a success" (Amuwo, 2011). 
Till this date this has not happened, the Commission's attempts to do so over the years "have been characterized primarily by delay, frustration and failure" (Human Rights Watch, 2011:19-20).

The poor quality of Nigeria's political leadership - the most conservative and neo-military wing of the political elite has been in power since May 1999 - has been the major clog in the wheel of the country's anti-corruption drive. To be sure, also to be factored in are institutional flaws, systemic crisis, the criminality in the country's political process, a system that aids, abets and rewards corruption and the commission's tendency to pander to the appointing authority (Human Rights Watch, 2011:19-20). The culture of impunity has been reinforced by lack of conviction. The removal of the commission's chief executive from power by the president can hardly be imputed to lack of performance by the latter. It is evidently a tongue-in-the-cheek argument to say that Waziri's sack - to cite only her example - on 22 November 2011 was due to her non-performance. It is instructive that the government did not give any reason for her sack.

\subsection{Conclusion}

Our submission is that former attempts to cleanup corruption have all failed because the leaders do not understand the dialectics of corruption and the strategies were not properly directed to address it. This is, of course in relation to other faults that have been identified earlier. Every attempt at handling corruption had adopted a holistic conceptualization of corruption which has led to the belief in a uni-linear notion of causation of corruption and a rather simplistic perception of its solution. A major submission of this paper is to argue that corruption is made up of component parts and every effort to eradicate corruption but which views it as a holistic concept will always fail. In an earlier paper, (Agarah 1995) we have argued that this reflects a naivety which Nigerian politicians and some scholars have accepted. For instance, Olowu (1983:294) had opined that a good and strong leadership would solve the problem of corruption while Hope (1985:6) has also reflected this assumption that "corruption can be rooted out only when the politicians choose to root it out." These opinions do not reflect and also deny the dynamics and the dialectical underpinning that exist within corruption and by so doing, exhibits ignorance of the reality of the historical linkage involved in the understanding of corruption in Nigeria. Our thesis is that corruption in Nigeria can be categorized into three types; political corruption, bureaucratic corruption and corruption of the bureaucratic process. It is within this conceptualization of corruption that its incidents, endemic nature, and prevalence can be understood and efforts to eradicate it can yield results. It is within this conceptualization that we can understand that corruption is in a systemic relation to each other, one begets the other and so any attempt to tackle one while leaving the other will end in futility. This apparent misunderstanding and failure to view it this way has led to many works isolating bureaucratic corruption and treating it as if it is distinct and different from political corruption (Mbaku, 1991, 1992, 1994).

\section{References}

Admolekun, L. (1985). The Fall of the Second Republic, Ibadan, Spectrum Books

Adebanwi, Wale (2012), Authority Stealing: Anti-Corruption War and Democratic Politics in Post-military Nigeria, Carolina: Carolina Academic Press

Adeseri, L. (2011) EFCC moves against Daniel, Akala, 7 others. Vanguard, 16 May.

Agara, T. (1990). Checks and Balances of Bureaucratic Excesses and Corruption in Nigeria; An Assessment of the Public Complaints Commission. African Administrative Studies, no. 35, pp. 60-75

Agara, T. (1992). The Military and Administrative Reforms: A Critical Look at the 1988 Reforms in Nigeria. Nigerian Association of Public Administration and Management (NAPAM) Journal, vol.2.

Agarah, T. (1995). Political Corruption, Bureaucratic Corruption and Corruption of the Bureaucratic Process: An Assessment of the Military in Nigerian Politics. African Administrative Studies, no. 44, pp. 55-70

Agara, T. (2008). Military Role Perception and Motivation for Intervention in Politics: Towards Achieving a Stable Civil-Military Relations in Nigeria. Unpublished Doctoral Thesis, Department of Political Science and Public Administration, University of Benin, Benin-City, 2008

Almond, G.A and Powell Jr., G.B. (1966): Comparative Politics: A Developmental Approach, Boston, Little Brown Co.

Amuwo, K. (2011). Talking Right, Walking Wrong: Interrogating the Anti-CorruptionPolicy of the Goodluck Jonathan Government. Paper presented at a Three-Day International Conference on Corruption, Governance and Development in Nigeria. Organized by Aminu Kano Centre for Democratic Research and Training, Mambayya House, Bayero University, Kano in conjunction with United Nations Development Programme (UNDP) and United Nations Economic Commission for Africa (UNECA), Addis Ababa. December 6-8, 2011.

Bayley, D.H. (1966). The Effects of Corruption in a Developing Nation, Western Political

Quarterly, 19 (4), pp. 719-732.

Benson, G. (1978). Political Corruption in America, Lexington, Mass. 
Brasz, H.A. (1963). Some Notes on the Sociology of Corruption, Sociologica Neerlandica,

1, pp. 367-375

Caiden, N. (1979). Shortchanging the Public. Public Administration Review, May/June,

Caiden, N. and Caiden G. (1977). Administrative Corruption. Public Administration Review, May/June, pp. 231-245

Corpus, O.D. (1960). The Two Faces of Graft and Corruption, Sunday Times Magazine, July 24.

Eigen, P. (2000). TI Corruption Index 2000 (13 September),http://www.transparency.org/policy_research/surveysindices/cpi/previous_cp2000, accessed 15 February 2009.

Ekhomu, O. (1980). Fraud, Waste and Abuse in African Administration: Shortchanging the Public. Comparative Maladministration, October 6, pp. 25-45

Gardiner, J. and Lyman, T. (1978). Decisions for Sale: Corruption and reform in Land-use and Building Regulation, New York, Praeger.

Goodman, M. (1990). Preserving Privilege in Yucatan, in Heidenheimer, A.J.; Johnston,

M.; and LeVine, V.T. (eds.) Political Corruption: A Handbook. New Brunswick, N. J.: Transaction Publishers.

Griffith, E.S. (1974). A History of American City Government: 1900-1920. New York, Praegar.

Harch, E. (1993) Accumulators and Democrats: Challenging State Corruption in Africa. Journal of Modern African Studies 31(1), pp. 31-48.

Hope, K.R. (1985). Politics, Bureaucratic Corruption and Maladministration in the ThirdWorld. International Review of Administrative Science, 1, pp. 18-25

Human Rights Watch (2007), Chop Fine: The Human Rights Impact of Local Government Corruption and Mismanagement in Rivers State, Nigeria, 19, 2 (A), January.

Human Rights Watch (2007b), Criminal Politics: Violence, 'Godfathers' and Corruption in Nigeria, 19, 16 (A), October

Human Rights Watch (2011), Corruption on Trial? The Record of Nigeria's Economic and Financial Crimes Commission, August

Huntington, S.P. (1972): Political Order in Changing Societies, New Haven, Yale University Press.

Leff, N. (1964): Economic Development through Bureaucratic Corruption American Behavioural Scientist, 8, Nov.

Mbaku, J.M. (1991) Military Expenditures and Bureaucratic Competition for Rents. Public Choice 71(2): 19-31.

Mbaku, J.M. (1992) Bureaucratic Corruption as Rent-Seeking Behavior. Konjunkturpolitik (Germany) 38 (4), pp. 247265.

Mbaku, J.M. (1994) Bureaucratic Corruption and Policy Reform in Africa. Journal of Social, Political and Economic Studies 19(2): pp. 149-175.

McMullan, M. (1963): A Theory of Corruption, in The Sociological Review, 9, July

Mcmullan, M. (1970): Political Corruption: Readings in Comparative Analysis, New York, Holt, Rinehart and Winston

Nwabuzor, E.J.O. (2003): Corruption and Democracy, in F.E. Iyioha, V.O. Aghayere, and

P.O. Oviasuyi (eds): Rethinking Governance and Development in the $21^{\text {st }}$ Century, Ekpoma, Institute for Governance and Development, Ambrose Alli University.

Nye, J.S. (1967): Corruption and Political Development: A Cost Benefit Analysis, American Political Science Review, 61, June

Olowu, D. (1983). The Nature of Bureaucratic Corruption in Nigeria. International Review of Administrative Science, 3, pp. 201-218

Rose-Ackerman, S. (1978). Corruption: A Study in Political Economy, New York, Academic Press.

Smelser, N.J. (1971). Stability, Instability and the Analysis of Political Corruption, in

Barber, B. and Inkeles A. (eds). Stability and Social Change, Boston, Little Brown

Werlin, H.H. (1973) The Consequences of Corruption: The Ghanaian Experience. Political Science Quarterly 88(1): pp. 71-85.

World Bank (2000), Anti-Corruption in Transition: A Contribution to the Policy Debate, Washington, DC

Williams, Adebayo (2007), Democratic Regression in Africa, Africa Today, May, pp. 12-13 